\title{
FORMALIZATION OF THE EDUCATION FUNDING RULES AS A PUBLIC MANAGEMENT INSTRUMENT
}

\author{
Iryna Radionova', ${ }^{1}$ ira Usyk $^{2}$ \\ ${ }^{1}$ Prof. habil. Dr. Kyiv National Economic University named after Vadym Hetman: Peremohy Av., \\ 54/1. 03057 Kyiv, Ukraine and «KROK» University: 30-32 Tabirna St, 03113, Kyiv, Ukraine. Phon \\ +380506543511. E-mail irina.radionova@gmail.com \\ ${ }^{2}$ Assoc. Prof. Dr. Kyiv National Economic University named after Vadym Hetman: Peremohy Av., \\ 54/1.03057 Kyiv, Ukraine. Phone +380958986296. E-mail vivayoung70@gmail.com
}

\section{Received 1608 201; Accepted 02092019}

The authors of the article have assumed that public management of the economy must rely on certain formalized rules regarding funding certain spheres. The purpose of the article is to implement two interrelated approaches towards education funding rules formalization with an emphasis on the 'idea of the rule' and on the quantitative assessment of the density of relations between variables. The actual formalization of the rules was regarded by the authors as a substantiation - theoretical and econometric - of the links between endogenous variables, which in this study are indicators of education financing, and exogenous variables. Macroeconomic, resource, innovation indicators are considered as exogenous variables. Three equations have been obtained. They are interpreted as guidelines for the government's action plan, respectively, for certain changes initiated in the education funding process.

Key words: policy rules, education funding rules, educational sphere.

JEL Codes: E62, G28, I22.

\section{Introduction}

Education funding in accordance with the rules, as well as any other activity in public management which is subject to rules, has undeniable benefits. These are the benefits of transparency and clarity of government actions for the society. For transparency and clarity, the rules must be formalized in an appropriate way. We understand the formalization of government policy rules as a way of presenting judgments about the content (structure) of phenomena, events and, accordingly, intentions regarding actions. The government rules formalizing issue is of particular relevance for societies with incomplete institutional and economic reforms, where there is a lack of trust and responsibility between government and society.

The aim of this study is to attempt to formalize the education funding rules on the basis of the so-called, idea of the rule" and using an array of factual data on a group of countries with a high level of well-being and education.

Copyright (C 2019 The Authors. Published by Vytautas Magnus University. This is an open-access article distributed under the terms of the Creative Commons Attribution-NonCommercial 4.0 (CC BY-NC 4.0) license, which permits unrestricted use, distribution, and reproduction in any medium, provided the original author and source are credited. The material cannot be used for commercial purposes. 
The „idea of the rule“ is regarded as the hypothesis about the connection of education funding certain indicators, for instance, such as the share of expenditure on education in GDP or the share of expenditure on education in total public expenditures, etc., with other macroeconomic, resource, etc. indicators. The ,idea of the rule“ reflects certain proportions (balances) which ensure macroeconomic stability. This statement is in line with the provisions of the „Economic Governance: Guidelines for Effective Financial Management" document of Department of Economic and Social Affairs UN. In particular, this document notes that „The traditional rational for fiscal policy rules is macroeconomic stability" (Economic Governance, 2000).

The rationale for the education funding rules is based on an array of data for a group of countries, most of which (90\%) are EU countries ${ }^{1}$. In our opinion, this may be due to several circumstances. First, the governments of all EU Member States implement a coherent financial policy. And this is documented in the European Commission, for example, in the Six Pack, the Excessive Deficit Procedure, and the Excessive Imbalance Procedure. Secondly, in the EU there is an agreement between the governments of the countries regarding the educational sphere. We mean, for example, the current EU "Framework Program for Research and Innovation (Horizon 2020). Therefore, despite some differences in the national educational systems of the EU countries, they are implementing common educational trends. The latter, in our opinion, should be represented in the education funding rules.

The form of education funding rules submission for public administration practical purposes may be different. As it is well-known, the use of certain normative funding indicators for the rules institutionalization is a widespread phenomenon. In our view, some analytical advantages have rules that are presented as dependencies (equations) between variables. Therefore, the purpose of our study is theoretical and econometric substantiation of the rules-equations, in which indicators of education funding appear as endogenous (dependent) variables. And macroeconomic, resource, demographic, etc. variables appear as exogenous (influential) variables.

The achievement of the set goal - the formalization of the education funding rules - can contribute to solving a number of problems regarding Ukrainian education funding. After all, for decades the Ukrainian education has been facing the problem of financial standards non-fulfillment, lack of resources for educational reforms.

Considering what we have already stated about the aim of the study, we can clarify the research problem as follows. The main research question of this study is to improve government policy rules as a public management tool through in-depth analysis of variables relations regarding education funding.

The methodological basis for the research

The methodological basis of this study is formed by the works of macroeconomists who have created a new direction in science. It can be called the „theory of policy rules“.

1 1.Austria, 2.Belgium, 3.Bulgaria, 4.Great Britain, 5.Denmark, 6.Estonia, 7.Ireland, 8.Spain, 9.Italy, 10.Cyprus, 11.Latvia, 12.Lithuania, 13.Malta, 14.the Netherlands, 15.Germany, 16.Poland, 17.Portugal, 18.Romania, 19.Slovakia, 20.Slovenia, 21.Hungary, 22 Finland, 23.France, 24.the Czech Republic, 25.Sweden, 26.the USA, 27.Japan, 28.Australia 
In the middle of the twentieth century the works of prominent macroeconomists and, simultaneously, methodologists in macroeconomics such as W.Baumol, M.Friedman, A.Phillips stressed upon the importance of rules for the governments policy implementation.

The content and benefits of the „life by rules" are disclosed in the well-known work of the Nobel Prize laureates Kidland F., Prescot E. (1977). Considering the fundamental provisions of the rational expectations theory, these researchers formulated an idea which has a significant methodological value. They confirmed that the policy in which the government is trying to respond discretely to the current situation does not usually lead to better results, that is to goal maximization. „Rather, by relying on some policy rules, economic performance can be improved" - the paper noted.

A well-known economist Taylor (2001), back in 1993, substantiated and presented in the form of an equation a design called ,Taylor's rule“. He developed the theory of policy rules, among other things, by proposing a simple and clear definition of the rule as a government action plan. In accordance with this plan, the government should, under certain circumstances, apply specific instruments of influence on the economy. In fact, the „Taylor's rule“ as Taylor J. explained, ,... describes the change in the instruments that would accompany a rise in inflation or in real GDP relative to potential GDP“. It is Taylor J. who launched the approach toward policy rules formalization in the form of equations in macroeconomic science and management practice. Herewith, the equation variables were filed in the form of gaps between the actual and the equilibrium (potential, expected, long-term trend) values of the variables. This methodological approach is justified insofar as, according to Taylor J., the policy rule is the predictable necessary changes in the instruments of economic regulation. Naturally, changes should be evaluated through gaps. We have used the Taylor J. approach in the study to formalize the education funding rules, having applied the equation of relationship between the gaps of the corresponding variables.

The methodological basis of modern macroeconomic studies, along with other models, is formed by the so-called „The 3-Equation New Keynesian Model“, or ISPC-MR model. In this model MR is a Monetary Rule function. The prominent economists Clarida, Jordi, Gertler (1999), Woodford (2003), Carlin, Soskice (2005, 2006, 2010), Whelan (2015), Poutineau, Sobczak, Vermandel (2015) took part in this theoretical construction creation. In one of the works Carlin, Soskice (2005) explained the role of Monetary Rule (MR) implemented in the model as follows: "We focus on the explicit forward-looking optimization behaviour of the central bank. Monetary policy makers must diagnose the nature of shocks affecting the economy and forecast their impact". The implementation of the policy rule in the macroeconomic model is a methodologically important circumstance for the development of macroeconomic analysis and for the study of policy rules. First, it recognizes the objectivity of policy rules, like other functions of this model, namely: IS and PC functions. Secondly, in this way, the need regarding the submission of rules in the form of equations with specific 
parameter values has been confirmed, since functions are usually presented in the form of equations.

The methodological basis of this study is also formed by the econometrics toolkit. We took advantage of the panel research toolkit in view of the benefits that it generates for theoretical generalizations. We mean, above all, the combination of time-series and cross-sectional data for the extension of statistical database. It was such an extension which was important to us. As noted in the classical work of the well-known econometrist Green W. (2002) concerning models with panel data, "In more practical terms researchers have been able to use time-series cross-sectional data to examine issues that could not be studied in either cross-sectional or time-series settings alone".

When examining selected panel data that integrates cross-sectional and timeseries data, we apply the regression analysis method using the Multiply regression module procedure. The general view of the model for the set of panel data, in the simplest form, is described by the equation:

$$
Y=a_{0}+\sum_{i=1}^{n} b_{i} x_{i}
$$

where $\mathrm{b}$ is the effect of the influence of the factor $x_{i}$ on Y; $a_{0}$ is the free term of the equation.

\section{Research results and discussion}

In this study, we have assumed that policy rules can become effective public management tools in case they reflect the objective relationships between dependent (endogenous) and influential (exogenous) variables. We have also assumed that these relations can be formalized in the form of equations between the education funding indicators gaps, on the one hand, and other indicators gaps, on the other hand.

This study is based on the algorithm regarding education funding rules formation, which had been explained in our previous research (Radionova, Usyk V. 2018). Accordingly, six endogenous variables of education funding $\left(\mathrm{X} 1-\mathrm{X} 6^{2}\right)$ and three groups of exogenous variables have been used. These three groups are as follows:

- Macroeconomic stability and growth indices (consisting of five variables: X7 $\left.-\mathrm{X} 11^{3}\right)$

- Innovativeness indices (consisting of three variables: X12 - X144);

- Age pattern indices ( consisting of three variables: X15 - X $17^{5}$ ).

\footnotetext{
${ }^{2} \mathrm{X} 1$ - Government expenditure on education as a percentage of GDP (\%), X2- Expenditure on education as a percentage of total government expenditure (\%), X3 - Government expenditure on tertiary education as a percentage of total government expenditure on education (\%), X4 - Government expenditure per student, primary (\% of GDP per capita), X5 - Government expenditure per student, secondary (\% of GDP per capita), X6 - Government expenditure per tertiary student as \% of GDP per capita (\%)

${ }^{3}$ X7 -GDP per capita growth (annual \%), X8 - Population ages 15-64, \% of total, X9 - Unemployment, total (\% of total labor force) (modeled ILO estimate), X10 - General government debt total, \% of GDP, X11 - Labour productivity forecast ${ }^{4}$ X12 - Charges for the use of intellectual property, payments (\% of GDP), X13 - High-technology exports (\% of manufactured exports), X14 - Research and development expenditure (\% of GDP),

${ }^{5}$ X15 - Adult education level, Below upper secondary, \% of 25-64 year-olds, X16 - Adult education level, Upper secondary, \% of 25-64 year-olds, X17 - Adult education level, Tertiary, \% of 25-64 year-olds
} 
For calculations, statistical information for a group of 28 countries for a 10-year period $^{6}$ has been used.

We have used two approaches attempting to formalize the education funding rules in the form of equations.

The first approach is based on the idea of the priority of the theoretical hypothesis - "idea of the rule". Further on we searched econometric confirmation of this idea.

The second approach is based on the suggestion of the priority of the quantitative evaluation of the relationships between variables. Further on, there is an acceptable hypothesis to explain the revealed relationships.

Such duality in achieving our goal seems to us quite reasonable. After all, the approaches are related. The famous econometrist Berndt E. (1991) wrote about being doomed to coexistence, contradiction and interaction of the two approaches, emphasizing the theoretical and applied (quantitative) aspects.

Implementing the first approach, we came, first of all, from the fact that under the influence of education, the modern economy of many countries has become significantly more productive, innovative and informative. Therefore, three basic hypotheses (ideas) have been formulated as the basis for defining the education funding rules. They (hypotheses) can be conditionally defined as: „resource-productive“, "expenditure-debt", "innovative".

In support of the validity of the use of at least two of the three hypotheses proposed, we will use the results of the analytical research on modern European universities funding called "Public Funding Observatory Report 2017" (Pruvot, 2017). The authors of the study came to the conclusion that changes in the university education public funding should be considered taking into account developments in student numbers and GDP growth, as well as EU-level funding for research and innovation. This suggests that in the above-mentioned study, "resource-productive" and "innovative" hypotheses are present both as an assumption and as a confirmed result of the analysis.

The logic of the „resource-productive“ hypothesis consists in the idea of connection of public expenditures on education $\left(\frac{G_{e d}}{Y}\right)$ and achieved employment / unemployment level $\left(u^{\prime}\right)$, productivity $\left(\frac{Y}{T_{L}}\right)$, and economic growth $\left(g_{Y / L}\right)$. This link can be represented as follows

$$
\uparrow u_{\leftrightarrow}^{\prime} \frac{Y}{T_{L}} g_{Y / L} \frac{G_{e d}}{Y}
$$

\footnotetext{
6 1. DATA base OECD. - https://data.oecd.org/, 2. DATA base Eurostat. - http://ec.europa.eu/eurostat/data/database, 3. DATA base Unesco Institute for statistics - http://data.uis.unesco.org/Index.aspx, 4. DATA base World bank. ec.europa.eu/eurostat/data/database
} 


\section{Formalization of the Education Funding Rules as a Public Management Instrument Iryna Radionova, Vira Usyk}

The connection between public expenditures on education, on the one hand, and productivity and economic growth, on the other hand, has been repeatedly tested on various databases by many researchers. Among them, for example, there are such wellknown scientists as Schultz (1961), Denison (1979), Psacharopoulos (1987), Aschauer (1993) as well as modern researchers of this issue Lawanson (2015), McGivney, Winthrop (2016), Ying Sh.Liu (2016), Mallick, Pradeep, Kalandi (2016), Appiah Elizabeth (2017). For example, Idrees, Siddiqi (2013) in their work used panel data in 14 countries over the 17-year period and have drawn interesting conclusions regarding the connection between public expenditures on education and growth at the turn of the twentieth and twenty first century. As researchers have found, ,in case of developed countries, 1 dollar increase in public education expenditures brings 21.85 dollars increase in GDP. Whereas, in developing nations, 1 dollar increase in public expenditures in education brings an increase of 27.29 dollars in GDP" (Idrees, Siddiqi 2013). The indisputability of the connection between government expenditures on education and economic growth provides a basis for its (connection) reflection in the education funding rules.

The logic of „expenditure-debt" hypothesis is related to the idea of the interdependence of the expenditures on education as part of the ... total government expenditure $\left(\frac{G_{e d}}{G}\right)$, as well as public debt $\left(\frac{D}{Y}\right)$ and economic growth $\left(g_{Y / L}\right)$. It is clear that the economic growth rate, with other things being equal, changes the share of public debt in GDP. The connection of the mentioned variables can be represented as follows:

$$
\uparrow g_{Y / L \leftrightarrow} \frac{D}{Y} \leftrightarrow \frac{G_{e d}}{G}
$$

The ,expenditure-debt" hypothesis is tangent to the problem of the other state budget expenditures limitation by the expenditures of public debt interest. These other expenditures also include education costs. This problem is so obvious that it is debated not only in scientific publications, but also in the media. For example, in the New York Times in September 2018, an article with a sad conclusion was posted: „By 2020, we will spend more on interest than we do on kids, including education, The federal government could soon pay more in interest on its debt than it spends on the military, medicaid or children's programs" (Nelson, 2018). It is precisely because of the obvious connection between government expenditures on education and public debt that can be claimed to be represented in the education funding rule.

The hypothesis of ,innovation" is the idea of a connection between indicators that reflect the level of the economy innovation development and education funding indicators. Importantly, in the studies as regards the relation between education expenditures and economic growth one should take into account the fact that this relation is not direct but indirect. And research and development (R@D), as well as the introduction of new technologies, are usually considered as a mediating link. In this sense, the "innovation" hypothesis is regarded to be "built-in" in the "resource- 
productive" hypothesis. The emphasis on the innovative aspect of the education expenditures has been made in many papers, in particular, of McMahon (1984), Bartel, Lichtenberg (1988), Romer (1986, 1990).

While analyzing the "innovation" hypothesis we have used the available statistics in the form of indicators: «Charges for the use of intellectual property, payments $\left(\%\right.$ of GDP)» $\left(\frac{I n c_{\text {int }}}{Y}\right)$, „High-technology exports (\% of manufactured exports)“ $\left(\frac{E x_{R @ D}}{Y}\right)$, ,Research and development expenditure (\% of GDP)“ $\left(\frac{E x_{\text {tech }}}{E x}\right)$. Since three indicators of education financing were taken into account for checking the hypothesis - „Government expenditure on education as a percentage of $\operatorname{GDP}^{\text {“ }}\left(\frac{G_{e d}}{Y}\right)$, „Expenditure on education as a percentage of total government expenditure“ ( $\left.\frac{G_{e d}}{G}\right)$, „Government expenditure on tertiary education as a percentage of total government expenditure on education“ ( $\left.\frac{G_{\text {ed / tert }}}{G_{\text {ed }}}\right)$ - the ,innovation” hypothesis is represented in three variants as follows:

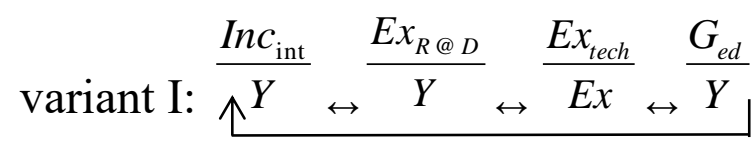
variant II: $\frac{I n c_{\text {int }}}{Y} \stackrel{E x_{R @ D}}{Y} \leftrightarrow \frac{E x_{\text {tech }}}{E x} \leftrightarrow \frac{G_{e d}}{G}$ variant III: $\uparrow^{Y} \leftrightarrow \frac{I n c_{\text {int }}}{Y} \leftrightarrow \frac{E x_{R @ D}}{E} \leftrightarrow \frac{E x_{\text {tech }}}{E x} \leftrightarrow \frac{G_{\text {ed Itert }}}{G_{e d}}$

The results of the analysis aimed at education funding rules formalization in accordance with the three hypotheses are given in Table 1 . The calculations have been carried out in the R-Studio environment, which makes it possible to evaluate at least nine characteristics of the models. The results of the models development, based on the logic of the „resource-productive“ hypothesis, are presented in Table 1 as Model 1, „expenditure and debt“" as Model 2, ,innovation“ - as models 3, 4, 5. 
Table 1. Results of regression analysis, according to the first approach

\begin{tabular}{|c|c|c|c|c|c|}
\hline $\begin{array}{l}\text { Results of } \\
\text { regression } \\
\text { analysis }\end{array}$ & $\begin{array}{c}\text { Model 1 } \\
\text { X1-X7,X9,X11 } \\
\text { "Resource- } \\
\text { productive" } \\
\text { hypothesis }\end{array}$ & $\begin{array}{c}\text { Model } 2 \\
\text { X2-X7,X10 } \\
\text { "Expenditure } \\
\text {-debt" } \\
\text { hypothesis }\end{array}$ & $\begin{array}{c}\text { Model 3 } \\
\text { X1- } \\
\text { X12,X13,X14 } \\
\text { "Innovation" } \\
\text { hypothesis } \\
\text { variant I }\end{array}$ & $\begin{array}{c}\text { Model } 4 \\
\text { X2- } \\
\text { X12,X13,X14 } \\
\text { "Innovation" } \\
\text { hypothesis } \\
\text { variant II }\end{array}$ & $\begin{array}{c}\text { Model 5 } \\
\text { X3- } \\
\text { X12,X13,X14 } \\
\text { "Innovation" } \\
\text { hypothesis } \\
\text { variant III }\end{array}$ \\
\hline $\begin{array}{l}\text { 1. Pair } \\
\text { correlations }\end{array}$ & $\begin{array}{l}\text { X1-X7: }-0,152 \\
\text { X1-X9: } 0,125 \\
\text { X1-X11:-0,187 } \\
\text { X7-X9:-0,159 } \\
\text { X7-X11: } 0,4 \\
\text { X9-X11: } 0,2\end{array}$ & $\begin{array}{l}\text { X2-X7: }-0,027 \\
\text { X2-X10: }-0,16 \\
\text { X7-X10: } 0,013\end{array}$ & $\begin{array}{l}\text { X1-X12: } 0,07 \\
\text { X1-X13:-0,087 } \\
\text { X1-X14: 0,14 } \\
\text { X12-X13: } 0,123 \\
\text { X12-X14:-0,077 } \\
\text { X13-X14:-0,032 }\end{array}$ & $\begin{array}{l}\text { X2-X12: } 0,02 \\
\text { X2-X13: } 0,0454 \\
\text { X2-X14: } 0,152 \\
\text { X12-X13: } 0,123 \\
\text { X12-X14:-0,077 } \\
\text { X13-X14:-0,032 }\end{array}$ & $\begin{array}{l}\text { X3-X12: } 0,038 \\
\text { X3-X13: } 0,207 \\
\text { X3-X14: }-0,006 \\
\text { X12-X13: } 0,123 \\
\text { X12-X14:-0,077 } \\
\text { X13-X14:-0,032 }\end{array}$ \\
\hline $\begin{array}{l}\text { 2.Multiple } \\
\text { R-squared }\end{array}$ & $\mathrm{R}_{\mathrm{mult}}=0,049$ & $\mathrm{R}_{\text {mult }}=0,025$ & $\mathrm{R}_{\mathrm{mult}}=0,027$ & $\mathrm{R}_{\mathrm{mult}}=0,02544$ & $\mathrm{R}_{\mathrm{mult}}=0,04323$ \\
\hline $\begin{array}{l}\text { 3. Equation } \\
\text { of the model }\end{array}$ & $\begin{array}{l}\mathrm{X} 1=-0.041- \\
0,0139 \mathrm{X} 7+ \\
0,0247 \mathrm{X} 9+4,9 \\
\mathrm{X} 11 \\
\end{array}$ & $\begin{array}{l}X 2=.-0,199- \\
0,011 X 7- \\
0,0357 X 10\end{array}$ & $\begin{array}{l}X 1=-0.047- \\
0,0747 X 12- \\
0,0308 X 13+0, \\
9213 X 14\end{array}$ & $\begin{array}{l}X 2=-0.2108- \\
0,0287 X 12- \\
0,0369 X 13- \\
2,0977 X 14\end{array}$ & $\begin{array}{l}\mathrm{X} 3=- \\
0.042+0,0736 \mathrm{X} 1 \\
2+0,1477 \mathrm{X} 13- \\
0,11634 \mathrm{X} 14\end{array}$ \\
\hline $\begin{array}{l}\text { 4. The } \\
\text { significance } \\
\text { of } \\
\text { regression } \\
\text { coefficient } \\
\text { (Prob } \\
(>t)<0,05)\end{array}$ & $\begin{array}{l}\text { The coefficient } \\
\text { for X7, X9 is } \\
\text { insignificant. } \\
\text { The coefficient } \\
\text { for X11 is } \\
\text { significant }\end{array}$ & $\begin{array}{l}\text { The } \\
\text { coefficient } \\
\text { for X7 is } \\
\text { insignificant. } \\
\text { The } \\
\text { coefficient for } \\
\text { X10 is } \\
\text { significant }\end{array}$ & $\begin{array}{l}\text { The coefficient } \\
\text { for X12, X13 } \\
\text { is insignificant. } \\
\text { The coefficient } \\
\text { for X14 is } \\
\text { significant }\end{array}$ & $\begin{array}{l}\text { The coefficient } \\
\text { for X12, X13 is } \\
\text { insignificant. } \\
\text { The coefficient } \\
\text { for X14 is } \\
\text { significant }\end{array}$ & $\begin{array}{l}\text { The coefficient } \\
\text { for X12, X14 is } \\
\text { insignificant. } \\
\text { The coefficient } \\
\text { for X13 is } \\
\text { significant }\end{array}$ \\
\hline $\begin{array}{l}\text { 5. Test } \\
\text { adequacy } \\
\text { criteria.(p- } \\
\text { value }<0,05)\end{array}$ & Adequate & Adequate & Inadequate & Inadequate & Adequate \\
\hline $\begin{array}{l}\text { 6.Autocorr } \\
\text { elation D- } \\
\text { W statistic }\end{array}$ & $\begin{array}{l}\mathrm{DW}=1,96- \\
\text { absent }\end{array}$ & $\begin{array}{l}\text { DW=1,97- } \\
\text { absent }\end{array}$ & $\begin{array}{l}\mathrm{DW}=1,538- \\
\text { almost absent }\end{array}$ & $\begin{array}{l}\mathrm{DW}=1,583- \\
\text { almost absent }\end{array}$ & $\begin{array}{l}\mathrm{DW}=1,7456- \\
\text { almost absent }\end{array}$ \\
\hline $\begin{array}{l}7 . \text { Tests } \\
\text { White } \\
\text { Heterosked } \\
\text { asticity }\end{array}$ & Absent & Absent & Present & Present & Absent \\
\hline $\begin{array}{l}\text { 8.Shapiro- } \\
\text { wilk } \\
\text { normality } \\
\text { test }\end{array}$ & Not confirmed & $\begin{array}{l}\text { Not } \\
\text { confirmed }\end{array}$ & Not confirmed & Not confirmed & Not confirmed \\
\hline $\begin{array}{l}\text { 9. Akaike } \\
\text { informatio } \\
n \text { criterion } \\
(\mathrm{AIC}(\mathrm{fm} 1))\end{array}$ & $\mathrm{AIC}=638,84$ & $\begin{array}{l}\mathrm{AIC}=1081,5 \\
9\end{array}$ & $\mathrm{AIC}=638,84$ & $\mathrm{AIC}=1069,93$ & $\mathrm{AIC}=905,648$ \\
\hline
\end{tabular}


To assess the models development results presented in Table 1, the following criteria have been used: 1) the desirability of higher values of pair correlation indices; 2) the desirability of higher values of multiple R-squared correlations; 3) signs with coefficients in the equation of a model which would correspond to the objective content of the connections between variables, 4) the significance (for Prob (t)) of coefficients under models variables, 5) the adequacy of models as the main criterion for the further use of the analysis results, 6) the absence of auto-correlation, 7) the absence of heteroscedasticity, 8) normality of residues distribution, 9) achievement of the lowest values of the indicator in accordance with the Akaike test.

On the basis of the information given in Table 1, the following conclusions can be made: out of the five models, only three models (1,2 and 5) proved to be adequate, therefore, only these models can be used in further analysis, models 3 and 4 should be rejected for further analysis not only as inadequate but also as those in which heteroscedasticity is observed, unfortunately, all models, including those which turned out to be adequate, have low multiple R-squared correlations indicators, that is, exogenous variables taken into account in models do not explain much of the content of education funding indicators, in all models there is no normal distribution of residues, which is fully consistent with low correlation indicators, unfortunately, in all models, which proved to be adequate, there are variables with insignificant coefficients, which worsens the quality of models, and therefore the reliability of further analysis on their basis.

Model 1 turned out to be the best of the five models, as we see. If the logic of our contemplation is for good reason, the ,resource-productive“ hypothesis is the most suitable for use in formalizing the education funding rules. We tried to improve Model 1 in two steps: 1) having modified the variable X11 for its better explanatory capacity, 2) having removed the variable $X 9$ from the Model - „Unemployment, total (\% of total labor force)", which has the least significant coefficient.

Parameters of the improved Model 1 are given in Table 2.

Table 2. Results of regression analysis for the improved Model 1

\begin{tabular}{|l|l|}
\hline Results of regression analysis & $\begin{array}{l}\text { Model 1 (improved) X1-X7,X11 } \\
\text {,Resource-Productive” hypothesis }\end{array}$ \\
\hline 1. Pair correlations & $\mathrm{X} 1-\mathrm{X} 7:-0,193 ; \mathrm{X} 1-\mathrm{X} 11:-0,083 ; \mathrm{X} 7-\mathrm{X} 11: 0,71$ \\
\hline 2.Multiple R-squared & $\mathrm{R}_{\text {mult }=0,043}$ \\
\hline 3. Equation of the model & $\mathrm{X} 1=-0.04-0,0665 \mathrm{X} 7-0,0361 \mathrm{X} 11$ \\
\hline $\begin{array}{l}\text { 4. The significance of regression } \\
\text { coefficient }(\text { Prob }(>\mathrm{t})<0,05)\end{array}$ & $\begin{array}{l}\text { The coefficient for X11 is insignificant. } \\
\text { The coefficient for X7 is significant }\end{array}$ \\
\hline 5. Test adequacy criteria.(p value $<0,05)$ & Adequate \\
\hline 6.Autocorrelation D-W statistic & DW=1,93- normal \\
\hline 7. Tests White Heteroskedasticity & Absent \\
\hline 8.Shapiro-wilk normality test & Not confirmed \\
\hline $\begin{array}{l}\text { 9. Akaike information criterion } \\
\text { (AIC(fm1)) }\end{array}$ & AIC $=500,712$ \\
\hline
\end{tabular}




\section{Formalization of the Education Funding Rules as a Public Management Instrument Iryna Radionova, Vira Usyk}

An attempt to improve the model of the highest quality did not give noticeable positive results, in compliance with the multiple correlation indicator. But, according to the Akaike test, the model has become slightly better.

In case the acquired equation of the Model 1 , and namely X1=-0.04-0,0665X7$0,0361 \mathrm{X} 11$ can be interpreted as education funding rule, the result can be formulated as follows: "The Government should plan an increase in the gap between the actual values of the «Government expenditures on education as a percentage of GDP» indicator from the expected under the condition of reduction gap between the actual values of the «GDP per capita growth» indicator and its equilibrium values and with a decrease in the gap between the «Labor productivity forecast index» and its equilibrium values".

Implementing the second approach, which, as has already been mentioned, involves an emphasis on the applied modeling side, we started evaluating pair correlations among all 17 endogenous and exogenous variables. Then, for variables with the largest correlation links, gaps have been identified between actual values and trend values. And then the models have been built. The models building results are presented in Table 3.

Table 3. Regression analysis results in accordance with the second approach

\begin{tabular}{|c|c|c|c|c|c|}
\hline $\begin{array}{l}\text { Regression } \\
\text { analysis } \\
\text { results }\end{array}$ & $\begin{array}{l}\text { Model 6 } \\
\text { X1-X15,X17 }\end{array}$ & $\begin{array}{l}\text { Model } 7 \\
\text { X6-X14,X15,17 }\end{array}$ & $\begin{array}{l}\text { Model } 8 \\
\text { X5-X7,X8 }\end{array}$ & $\begin{array}{l}\text { Model } 9 \\
\text { X2-X15,X17 }\end{array}$ & $\begin{array}{l}\text { Model 10 } \\
\text { X2- } \\
\text { X8,X9,X10 }\end{array}$ \\
\hline $\begin{array}{l}\text { 1. Pair } \\
\text { correlations }\end{array}$ & $\begin{array}{l}\text { X1-X15: } 0,164 \\
\text { X1-X17: 0,064 } \\
\text { X15-X17:-0,35 }\end{array}$ & $\begin{array}{l}\text { X6-X14: 0,0282 } \\
\text { X6-X15: 0,0299 } \\
\text { X6-X17: 0,1577 } \\
\text { X14-X15: 0,22 } \\
\text { X14-X17:-0,099 } \\
\text { X15-X17: :-0,35 }\end{array}$ & $\begin{array}{l}\text { X5-X7:-0,288 } \\
\text { X5-X8: 0,274 } \\
\text { X7-X8:-0,264 }\end{array}$ & $\begin{array}{l}\text { X2-X15:0,02 } \\
\text { X2-X17: 0,009 } \\
\text { X15-X17: :-0,35 }\end{array}$ & $\begin{array}{l}\text { X2-X8: } 0,043 \\
\text { X2-X9: } 0,20 \\
\text { X2-X10: } 0,16 \\
\text { X8-X9:-0,168 } \\
\text { X8-X10:-0,40 } \\
\text { X9-X10: } 0,45\end{array}$ \\
\hline $\begin{array}{l}\text { 2.Multiple R- } \\
\text { squared }\end{array}$ & $\mathrm{R}_{\mathrm{mult}}=0,044$ & $\mathrm{R}_{\mathrm{mult}}=0,02715$ & $\mathrm{R}_{\text {mult }}=0,1253$ & $\mathrm{R}_{\text {mult }}=0,00025$ & $\mathrm{R}_{\text {mult }}=0,046$ \\
\hline $\begin{array}{l}\text { 3. Equation } \\
\text { of the model }\end{array}$ & $\begin{array}{l}X 1=-0.041- \\
0,173 X 15+ \\
0,164 X 17\end{array}$ & $\begin{array}{l}X 6=0,0235+0,00 \\
57 X 15+ \\
0,0708 X 17\end{array}$ & $\begin{array}{l}\mathrm{X} 5=- \\
0.07386- \\
0,18376 \mathrm{X} 7+ \\
2,1314 \mathrm{X} 8 \\
\end{array}$ & $\begin{array}{l}X 2=- \\
0.107+0,0199 X \\
15-0,00055 X 17\end{array}$ & $\begin{array}{l}X 2=-0.1634- \\
0,1212 \times 8- \\
0,1177 X 9- \\
0,0212 X 10\end{array}$ \\
\hline $\begin{array}{l}\text { 4. The } \\
\text { significance } \\
\text { of regression } \\
\text { coefficient } \\
\text { (Prob } \\
(>\mathrm{t})<0,05)\end{array}$ & $\begin{array}{l}\text { The } \\
\text { coefficients } \\
\text { for all X are } \\
\text { significant }\end{array}$ & $\begin{array}{l}\text { The coefficients } \\
\text { for all } \mathrm{X} \text { are } \\
\text { insignificant }\end{array}$ & $\begin{array}{l}\text { The } \\
\text { coefficients } \\
\text { for all X are } \\
\text { significant }\end{array}$ & $\begin{array}{l}\text { The coefficients } \\
\text { for all X are } \\
\text { insignificant }\end{array}$ & $\begin{array}{l}\text { The } \\
\text { coefficients } \\
\text { for X8, X10 } \\
\text { are } \\
\text { insignificant. } \\
\text { The } \\
\text { coefficients } \\
\text { for X9 are } \\
\text { significant }\end{array}$ \\
\hline $\begin{array}{l}5 . \text { Test } \\
\text { adequacy } \\
\text { criteria. }(\mathrm{p}- \\
\text { value }<0,05)\end{array}$ & Adequate & Inadequate & Adequate & Inadequate & Adequate \\
\hline
\end{tabular}




\begin{tabular}{|c|c|c|c|c|c|}
\hline $\begin{array}{l}\text { 6.Autocorrel } \\
\text { ation D-W } \\
\text { statistic }\end{array}$ & $\begin{array}{l}\text { DW=1,937- } \\
\text { absent }\end{array}$ & $\begin{array}{l}\text { DW=1,8207- } \\
\text { absent }\end{array}$ & $\begin{array}{l}\text { DW=1,538- } \\
\text { almost } \\
\text { absent }\end{array}$ & $\begin{array}{l}\text { DW=2,036 - } \\
\text { absent }\end{array}$ & $\begin{array}{l}\text { DW=1,55- } \\
\text { almost } \\
\text { absent }\end{array}$ \\
\hline $\begin{array}{l}\text { 7. Tests } \\
\text { White } \\
\text { Heteroskedas } \\
\text { ticity }\end{array}$ & Present & Absent & Absent & Absent & Absent \\
\hline $\begin{array}{l}\text { 8.Shapiro- } \\
\text { wilk } \\
\text { normality } \\
\text { test }\end{array}$ & Not confirmed & Not confirmed & $\begin{array}{l}\text { Not } \\
\text { confirmed }\end{array}$ & Not confirmed & $\begin{array}{l}\text { Not } \\
\text { confirmed }\end{array}$ \\
\hline $\begin{array}{l}\text { 9. Akaike } \\
\text { information } \\
\text { criterion } \\
(\mathrm{AIC}(\mathrm{fm} 1))\end{array}$ & $\mathrm{AIC}=487,216$ & $\mathrm{AIC}=44,6936$ & $\begin{array}{l}\mathrm{AIC}=1312,1 \\
99\end{array}$ & $\mathrm{AIC}=798,458$ & $\begin{array}{l}\mathrm{AIC}=1077,4 \\
14\end{array}$ \\
\hline
\end{tabular}

Based on the information presented in Table 3, we can make such generalizations:

- out of five models three of them - models $6,8,10$ - have appeared to be adequate, and two of them did not reveal heteroscedasticity;

- all adequate models show low Multiple R-squared correlation, but Model 8 has appeared to be the best (Rmult $=0,1253)$;

- the low correlation is consistent with the unconfirmed normality of the residues distribution;

- for all models variables, except for Model 10, the coefficients were significant, indicating a sufficient quality of models.

According to the logic of the second approach, the equation of adequate models must be interpreted from the standpoint of certain hypotheses. The interpretation, in our opinion, may be as follows.

Model 6 can be considered as a manifestation of the "resource" hypothesis simplified version. After all, this model has confirmed the adequacy of the connection between „Government expenditure on education as a percentage of GDP” (X1), on the one hand, and two human resources quality indicators - "Adult education level, Below upper secondary, \% of 25-64 year-olds" (X15) and "Adult education level, Tertiary, \% of 25-64 year-olds" (X17), - on the other hand.

Model 8 can be explained from the standpoint of a "resource-productive" hypothesis. Since it reflects the connection between "Government expenditure per student, secondary (\% of GDP per capita) (X5)" indicator, on the one hand, and „Population ages 15-64, \% of total” (X8) and national economy general effectiveness indicator „GDP per capita growth (annual \%)" (X7) labour resources indicator, on the other hand.

Model 10 can be interpreted from the standpoint of the mixed "resource-debt" hypothesis insofar as it presents a link between „Expenditure on education as a percentage of total government expenditure (\%)" (X2) indicator, on the one hand, and 
„Population ages 15-64, \% of total” (X8), „Unemployment, total (\% of total labor force)" (X9) two resource indicators as well as "General government debt total, \% of GDP" (X10) one expenditure-debt indicator, on the other hand.

If the logic of our reasoning is grounded, Model 8 and Model 10 may be used to formalize the rules for education funding.

The equation X5 $=-0.07386-0,18376 \times 7+2,1314 \times 8$ received in Model 8 as a rule, can be worded as follows: „The government should plan an increase in the gap between the actual and the expected „Government expenditure per student, secondary (\% of GDP per capita)" indicator, in case the gaps of the variables "GDP per capita growth (annual \%)” and „Population ages 15-64, \% of total” ... decrease.

To interpret the Model 10 equation as a funding rule, we tried to improve the model. For this purpose, the variable with the worst value of the coefficient, which was the variable X8 (Prob $(\mathrm{t}))=0,72)$, has been withdrawn from the model. The parameters of Model 10 after the improvement attempt are presented in Table 4.

Table 4. Results of regression analysis of Model 10 after the improvement attempt

\begin{tabular}{|l|l|}
\hline Regression analysis results & $\begin{array}{l}\text { Model 10 (after the improvement attempt) } \\
\text { X2-X9,X10 } \\
\text { hypothesis }\end{array}$ \\
\hline 1. Pair correlations & X2-X9: 0,20 \\
& X2-X10: 0,157 \\
& X9-x10: 0,45 \\
\hline 2.Multiple R-squared & $\mathrm{R}_{\text {mult }=0,046}$ \\
\hline 3. Equation of the model & X2 $=-0.1643-0,118 \mathrm{X} 9-0,0197 \mathrm{X10}$ \\
\hline $\begin{array}{l}\text { 4. The significance of regression coefficient } \\
\text { (Prob }(>\mathrm{t})<0,05)\end{array}$ & $\begin{array}{l}\text { The coefficient for X10 is insignificant. } \\
\text { The coefficient for X9 is significant }\end{array}$ \\
\hline 5. Test adequacy criteria.(p-value $<0,05)$ & Adequate \\
\hline 6.Autocorrelation D-W statistic & DW=1,548- almost absent \\
\hline 7. Tests White Heteroskedasticity & Absent \\
\hline 8.Shapiro-wilk normality test & Not confirmed \\
\hline 9. Akaike information criterion $(\mathrm{AIC}(\mathrm{fm} 1))$ & AIC $=1075,535$ \\
\hline
\end{tabular}

The Model 10 quality improvement due to the removal of the variable X8, according to the correlation indicator, unfortunately, did not occur. There was only a very small positive change, according to the Akaike test.

The equation obtained in the updated Model 10 X2=-0.1643-0,118X9 0,0197X10 can be interpreted as a rule in the following way: „The government should plan an increase in the gap between expenditure on education as a percentage of total government expenditure" indicator and its expected meanings, if the gaps of the variables „Unemployment, total (\% of total labor force)” and „General government debt total, $\%$ of GDP" decrease. 


\section{Conclusions}

The conducted study, in general, confirmed our initial assumption that regression analysis tools could be used to better validate government policy rules and formalize them as equations.

The formalization of the education funding rules has been carried out in the process of combining the "idea of rules" (certain theoretical hypotheses) and modeling of the relations between education funding indicators and other exogenous variables.

This formalization has resulted in the development of three equations, which, in our opinion, can be interpreted as rules by a certain level of reliability. These are rules in the sense of the Government's action plan for the financing of education on the basis of the dependencies which have developed in this area. We have obtained three adequate models, presented by equations with significant coefficients for variables:

$$
\begin{aligned}
& \text { gap } \frac{\frac{G_{e d}}{Y}=-0.04-0,0665 \text { gap g } \mathrm{g}_{\mathrm{Y} / \mathrm{L}}-0,0361 \mathrm{gap}}{\frac{Y}{T_{L}}} \\
& \text { gap } \frac{G_{e d / \text { sec. } s t}}{Y_{/ L}}=-0.07386-0,18376 \text { gap } \mathrm{g}_{\mathrm{Y} / \mathrm{L}}+2,1314 \frac{N_{15-64}}{N} \\
& \text { gap } \frac{G_{e d}}{G}=-0.1643-0,118 \text { gap } u^{\prime}-0,0197 \mathrm{X} \text { gap } \frac{D}{Y}
\end{aligned}
$$

The government's action plans, which result from the obtained equations, generally include three positions: 1) taking into account changes in economic growth rates, and changes in labor productivity, when determining the share of public expenditure on education; 2) taking into account labour productivity change and changes in the proportion of the population of working age, when financing the cost of education for one student in a secondary school; 3) taking into account changes in the level of unemployment and the share of public debt in GDP, when determining the share of education expenditures in general state expenditures.

The implementation of the proposed approach to the formalization of the rules for financing education has revealed certain limitations. First, the required level of explanatory capability of the models has not been achieved due to low multiple Rsquared correlations. Secondly, as a counterargument, we may advance a thesis regarding the differences in education funding mechanisms in the analyzed countries, whose statistics have been used. Therefore, the proposed equations can only reflect very general relationships and dependencies.

We find the established limitations as benchmarks for the future improvement of the approach to rules formalization, and not as arguments to refuse attempts of such formalization. 


\section{References}

Appiah Elizabeth N. (2017). The Effect of Education Expenditure on Per Capita GDP in Developing Countries. International Journal of Economics and Finance. Vol. 9, No. 10: 136-144.

Aschauer, D.A. (1993). Is Public Education Productive? // Higher Education and Economic Growth Editors: Becker Jr., William E., Lewis, D.R. (Eds.)

Bartel, A.P., Lichtenberg, F.R. (1987). The comparative advantage of educated workers in implementing new technology// Review of Economics and Statistics. 69(1): 1-11.

Berndt, Ernst R. (1991). The practice of econometrics: Classical and contemporary.- AddisonWesley Publishing company, Reading, Mass. 702 pp.

Carlin, W. and Soskice D. (2006), Macroeconomics: Imperfections, Institutions and Policy, Oxford University Press. 852 p.

Carlin, W. and Soskice D. (2010). A New Keynesian Open Economy Model for Policy Analysis // CEPR Discussion Paper. № 7979.

Carlin, W., Soskice, D. (2005) The 3-Equation New Keynesian Model - a Graphical Exposition. - https://www.ucl.ac.uk/ uctpa36/3equation_2005_withtitle.pdf [2019 05 24].

Clarida, R., Jordi G., Gertler M. (1999). The Science of Monetary Policy: A New Keynesian Perspective // Journal of Economic Literature, 37 (4): 1661-1707.

Denison, E. (1979). Accounting for slower economic growth: The United States inthe 1970s. Washington, D.C.: Brookings Institution.

Economic Governance: Guidelines for Effective Financial Management (2000). https://publicadministration.un.org/publications/content/PDFs/E-

Library\%20Archives/2000\%20Economic\%20Governance_Guidelines\%20for\%20Effective\%20Fin ancial\%20Management.pdf [2019 05 24].
Green,
$\mathrm{W}$.
Econometric
Analysis
(2002).

https://spu.fem.uniag.sk/cvicenia/ksov/obtulovic/Manaž.../EconometricsGREENE.pdf [2019 05 24].

Horizon 2020. Official Documents. - https://ec.europa.eu/programmes/horizon2020/en/officialdocuments [2019 05 24].

Idrees A., Siddiqi W. (2013). Does Public Education Expenditure Cause Economic Growth? Comparison of Developed and Developing Countries // Pakistan Journal of Commerce and Social Sciences. Vol. 7 (1): 174-183

Kydland, F., Prescott, E.(1997). Rules Rather than Discretion: The Inconsistency of Optimal Plans // The Journal of Political Economy. Vol. 85. No. 3: 473-492.

Lawanson Akanni Olayinka (2015). Economic Growth Experience of West African Region: Does Human Capital Matter? International Journal of Business and Social Science, Vol. 6, No. 12.

Mallick Lingaraj, Pradeep Kumar Das, Kalandi Charan Pradhan (2016). "Impact of educational expenditure on economic growth in major Asian countries: Evidence from econometric analysis". Theoretical and Applied Economics, Volume XXIII, No. 2(607), Summer: 173-186.

McGivney Eileen, Winthrop Rebecca (2016). Education's Impact on Economic Growth and Productivity. - https://www.brookings.edu/wp-content/uploads/2017/12/educations-impact-onproductivity.pdf [2019 05 24].

McMahon, W.W. (1984). The relation of education and R\&D to productivity growth // Economics of Education Review. No 3: 299-313.

Nelson, D. Schwartz (2018). As Debt Rises, the Government Will Soon Spend More on Interest Than on the Military. - https://www.nytimes.com/2018/09/25/business/economy/us-governmentdebt-interest.html 2017.html [2019 05 24].

https://eua.eu/resources/publications/718:eua-public-funding-observatory-

Poutineau Jean-Christophe, Sobczak Karolina, Vermandel Gauthier (2015). The analytics of the New Key-nesian 3-equation Model. - https://hal.archives-ouvertes.fr/hal-01194642 [2019 05 24]. 
Pruvot, E.B., Estermann, T., Kupriyanova, V. (2017). Public Funding Observatory Report. https://eua.eu/resources/publications/718:eua-public-funding-observatory-2017.html [2019 05 24].

Psacharopoulos, G. (1987). Returns of education: A further international update and implications // Journal of Human Resources, 20(4): 581-604.

Radionova, I., Usyk, V. (2018). Financial policy rules in the educational sphere: substantiation algorithm // Management Theory and Studies for Rural Business and Infrastructure Development. Vol.40., No.3: 163-174.

Romer, P. (1986). Increasing Returns and Long-Run Growth // The Journal of Political Economy. Vol. 94, No. 5:1002-1037

Romer, P. (1990). Endogenous Technological Change // The Journal of Political Economy. Vol. 98, No. 5:71-102

Schultz, T.W. (1961). Education and economic growth. In N.B. Henry (Ed.). - Social forces influencing American education. Chicago: University of Chicago Press.

Taylor, J. (2001). Using Monetary Policy Rules in Emerging Market Economies. https://web.stanford.edu/ johntayl/Onlinepaperscombinedbyyear/2001/Using_Monetary_Policy_Ru les_in_Emerging_Market_Economies.pdf [2019 05 24].

Whelan K. (2015). Advanced Macroeconomics Notes, University College Dublin. https://www.karlwhelan.com/Macro2/Notes1.pdf [2019 05 24].

Woodford, M. (2003). Interest and Prices: Foundations of a Theory of Monetary Policy.

\title{
ŠVIETIMO FINANSAVIMO TAISYKLIŲ FORMALIZAVIMAS KAIP VIEŠOJO VALDYMO PRIEMONE்
}

\author{
Iryna Radionova ${ }^{1}$, Vira Usyk $^{2}$ \\ ${ }^{1,2}$ Kyiv National Economic University named after Vadym Hetman
}

\section{Gauta 201908 16; Priimta 20190902}

Straipsnio autoriai padare prielaidą, kad viešasis ekonomikos valdymas turi remtis tam tikromis oficialiomis taisyklėmis, susijusiomis su tam tikrų sričių finansavimu. Straipsnio tikslas - pritaikyti $\mathrm{du}$ tarpusavyje susijusius švietimo finansavimo taisyklių įforminimo metodus, akcentuojant „taisyklès idèją" ir kiekybinį santykių tarp kintamųjų tankio vertinimą. Faktinis taisyklių įforminimas autoriu buvo vertinamas kaip endogeninis kintamasis, kuris šiame tyrime yra švietimo finansavimo rodikliai. Išorinių kintamųų sąsajų pagrindimas buvo atliekamas priraikius teorinius ir ekonometrinius metodus. Makroekonominiai, išteklių, inovacijų rodikliai laikomi išoriniais kintamaisiais. Gautos trys lygtys. Jos yra aiškinamos kaip vyriausybès veiksmų plano gairès, susijusios su tam tikrais švietimo finansavimo proceso pakeitimais.

Raktiniai žodžiai: politikos taisyklès, švietimo finansavimo taisyklès, švietimo sritis.

JEL kodai: E62, G28, I22 